\title{
ONLINE MONITORING KUALITAS AIR WADUK BERBASIS THINGSPEAK
}

\author{
Son Ali Akbar, Dimas Baskoro Kalbuadi*), Anton Yudhana \\ Program Studi Teknik Elektro, Universitas Ahmad Dahlan Yogyakarta \\ Kampus IV, Jl. Ringroad Selatan, Kragilan, Tamanan, Banguntapan, Bantul, \\ Daerah Istimewa Yogyakarta 55191 \\ ${ }^{*}$ E-mail: dimaskalbuadi17@gmail.com
}

\begin{abstract}
Abstrak
Waduk merupakan salah satu sarana penampungan sementara sumber air. Sumber air memiliki peranan yang penting bagi mahluk hidup dalam memenuhi kebutuhannya. Akan tetapi, kualitas air perlu dijaga untuk mengurangi risiko pencemaran yang berdampak pada lingkungan hidup. Penelitian ini bertujuan merancang bangun prototipe untuk monitoring kualitas air secara online pada sebuah waduk. Parameter ukur untuk menentukan kualitas air yakni deteksi tingkat keasaman $(\mathrm{pH})$, kekeruhan $(\mathrm{NTU})$ dan suhu $\left({ }^{\circ} \mathrm{C}\right)$ pada air waduk. Prototipe terpasang sensor pH electrode, sensor turbidity dan sensor suhu (DS18B20). Hasil pembacaan data sensor disimpan pada database Thinkspeak secara real-time. Monitoring kualitas air dapat divisualisasikan pada Smartphone yang telah terpasang aplikasi ThingView. Parameter uji sistem dilakukan dengan pada pagi hari, siang hari, dan malam hari. Validasi sistem dilakukan dengan membandingkan parameter hasil ukur dengan alat ukur digital. Pengujian sistem diperoleh pada malam hari $(\mathrm{pH} 6,4)$ level keasaman lebih rendah, pada siang hari $(17,8 \mathrm{NTU})$ level kekeruhan lebih rendah, dan pada malam hari $\left(22^{\circ} \mathrm{C}\right)$ suhu lebih rendah. Selain itu, performa sistem telah menunjukkan prediksi kesalahan ukur yang minimum dari hasil perbandingan pengukuran.
\end{abstract}

Kata Kunci: Waduk, Kualitas air, Online monitoring

\begin{abstract}
The reservoir is one of the temporary storage facilities for water sources. Water sources have an essential role in living things in providing their needs. However, water quality needs to be maintained to reduce the risk of pollution that has an impact on the environment. This study aims to design prototypes for monitoring water quality online in a reservoir. The system used to determine water quality, such as acidity $(\mathrm{pH})$, turbidity (NTU) and temperature (OC) in reservoir water. The prototype is integrated into the electrode $\mathrm{pH}$ sensor, turbidity sensor and temperature sensor (DS18B20) furthermore, sensor data readings stored in the Thinkspeak database in real-time. Water quality monitoring can be visualized on a Smartphone that has the ThingView application installed. System testing is conducted in the morning, the daytime, and night. System validation is done by comparing the measurement results parameters with digital measuring devices. System testing is achieved by lower acidity level at night is pH 6.7, lower turbidity level at the daytime is $17.8 \mathrm{NTU}$, and lower temperature levels at night is $22^{\circ} \mathrm{C}$. Additionally, system performance accomplished the minimum measurement error result.
\end{abstract}

Keywords: Reservoir, Water quality, Online monitoring

\section{Pendahuluan}

Air mempunyai peranan yang sangat penting bagi kehidupan manusia, bahkan air waduk khususnya menjadi tumpuan masyarakat untuk aktivitas sehari-hari dan menjadi sumber mata pencaharian masyarakat seperti sebagai pengairan ke sawah-sawah petani, pembibitan ikan dan diperlukan sebagai kebutuhan masyarakat pada umumnya. Mengingat betapa pentingnya air bagi kehidupan manusia maka kualitas air harus tetap terjaga dan dipertahankan kebersihanya, lepas dari sampahsampah dan bebas dari zat asam dan basa agar tidak dapat merusak kualitas air.
Monitoring kualitas keasaman, kekeruhan dan suhu air sangat penting dilakukan untuk mengetahui baik buruknya kualitas air. Penyediaan air bersih dengan kualitas yang buruk dapat mengakibatkan dampak yang buruk bagi kesehatan masyarakat yaitu timbulnya berbagai penyakit. Perubahan kadar keasaman air juga dapat menyebabkan berubahnya bau, rasa dan warna pada air. Berdasarkan Peraturan Menteri Kesehatan (PERMENKES) terbaru tentang syarat-syarat dan pengawasan kualitas air bahwa standar kualitas air bersih yang baik yaitu memiliki kadar keasamaan yakni $\mathrm{pH}$ 6,59,0 [1][2]. Keberadaan air disekitar masyarakat kadang semakin menurun kualitasnya, air PDAM yang bersumber 
dari sungai dan air sumur masih menjadi andalan masyarakat indonesia dalam memenuhi kebutuhan akan air bersih [3][4]. Namun seringkali air yang digunakan masyarakat belum memenuhi uji kesehatan yang telah ditetapkan Menteri Kesehatan Republik Indonesia. Hal ini bisa dipengaruhi oleh semakin bertambahnya jumlah pabrik yang membuang limbah tanpa diolah ke sungai dan kualitas air juga dapat dipengaruhi dari kualitas tanah. Pengukuran $\mathrm{pH}$ air dapat dilakukan dengan menggunakan $\mathrm{pH}$ meter atau menggunakan kertas lakmus, cara ini hanya bisa dilakukan secara manual. Artinya, data hasil pengukuran dari $\mathrm{pH}$ meter harus langsung dicatat sehingga tidak dapat melakukan pengukuran secara realtime dari jarak jauh.

Sistem manual masih banyak terdapat kekurangan, seperti memerlukan waktu yang cukup lama dan keterlambatan dalam memberikan informasi atau laporan [5]. Penelitian yang dilakukan Sukamto, Perbandingan kualitas air danau dan PDAM berbasis web menggunakan komunikasi radio RF433. Hasil pengujian menunjukkan alat sudah dapat bekerja namum masih memiliki kekurangan yaitu pada pengiriman data jarak maksimal yang hanya dapat dijangkau 65 meter dan ruang terbuka, jika terdapat halangan seperti ruang atau tembok pengiriman sulit untuk mengirim data [6][7]. Pada penelitian ini akan dikembangkan sistem pemantauan kualitas air waduk dengan menggunakan Internet of Things untuk melakukan pemantauan kualitas air waduk dengan parameter kualitas air berdasarkan tingkat keasaman, kekeruhan, dan suhu. Selain itu nantinya hasil dari monitoring dapat dilihat pada web channel ThingSpeak dan sebagai pendukung dipasang aplikasi ThingView pada Smartphone Android untuk dapat menampilkan kembali langsung hasil visualisasi dari ThingSpeak pada Smartphone.

\section{Metodologi}

Pada penelitian ini metode yang digunakan ialah IoT (Internet of Things) dengan IoT maka untuk memantau kualitas air waduk dapat real-time dan online monitoring, selain itu proses uji coba dilakukan di sebuah waduk dekat pemukiman warga dengan dengan membandingan waktu pengukuran pada pagi hari, siang hari dan malam hari. Ada beberapa tahap pelaksanaan, pengembangan dan pengujian untuk memastikan sistem yang dikembangkan telah berjalan dengan baik. Pengembangan sistem pemantauan kualitas air waduk dengan metodologi yang digunakan ialah prototype. Tahapan pengembangan dibagi menjadi :

1. Implementasi Perangkat Keras dan Pengujian Sensor, pada tahap ini dikembangkan perangkat keras dan sensorsensor bekerja dengan baik. Ada 3 parameter uji yaitu tingkat keasaman, kekeruhan dan suhu dengan sensor yang digunakan ialah $\mathrm{pH}$ Electrode untuk mengukur tingkat keasaman, Turbidity Sensor digunakan untuk mengukur kekeruhan dan sensor DS18B20 untuk mengukur suhu dalam air waduk.

\section{Implementasi Monitoring Kualitas Air Waduk} Berbasis ThingSpeak, tahap ini dilakukan untuk pengembangan fitur pengiriman data melalui internet dengan modul yang digunakan ialah ESP8266-01s. Data hasil pembacaan sensor selanjutnya dikirimkan ke server web IP Channel ThingSpeak dan langsung tersimpan sebagai penyimpanan bersama dalam infrastruktur internet.

3. Implementasi Pemantauan menggunakan Aplikasi ThingView pada Smartphone, pada tahap ini menggunakan aplikasi ThingView yang merupakan aplikasi versi Android dari ThingSpeak yang dapat dipasang pada Smartphone. Hasil data dari ThingSpeak nantinya dapat ditampilkan kembali dengan menggunakan aplikasi ThingView pada Smartphone lebih rinci.

\subsection{Teknologi Internet of Things (IoT)}

Internet Of Things (IoT) merupakan sebuah konsep dimana suatu objek yang memiliki kemampuan untuk mentransfer data melalui jaringan tanpa memerlukan interaksi manusia ke manusia atau manusia ke komputer. IoT telah berkembang dari konvergansi teknologi nirkabel, micro-electromechanical systems (MEMS), dan Internet. IoT menciptakan jaringan kecil ini di antara perangkat sistemnya. Keuntungan ini telah menarik sebagian peneliti lingkungan dalam menerapkan IoT untuk memantau kondisi lingkungan termasuk parameter kualitas air [8][9].

Teknologi IoT memungkinkan pengendalian objek dari jarak jauh di seluruh infrastruktur jaringan yang ada dan mampu menciptakan peluang untuk integrasi antara dunia fisik dan sistem digital berbasis cyber sehingga dapat meningkatkan efesiensi, dan manfaat ekonomi. Setiap objek atau Things mampu diidentifikasi melalui sistem komputasi yang tertanam dan mampu beroperasi dalam jaringan internet [10].

Penelitian yang dilakukan Deni dkk. merancang sistem rancang bangun kualitas air yang bekerja secara sistematis dan berurutan menggunakan mikrokontroller ATmega328P menggunakan sensor $\mathrm{pH}$, DO, Ultrasonik, Modul GSM dan GPS serta PC sebagai server mampu menampilkan informasi mengenai data pengukuran kualitas air berdasarkan tanggal yang dipilih oleh pengguna. Sistem dapat menampilkan lokasi pengukuran kualitas air dalam dan mem-plotnya di Google Maps[11]. Penggunaan jaringan nirkabel WiFi dapat dimanfaatkan oleh ESP8266 sehingga sistem yang terhubung dapat mengirimkan data melalui jaringan Internet[12][13]. Selain digunakan untuk monitoring kualitas air, aplikasi teknologi IoT antara lain dapat digunakan untuk monitoring sistem energi dan cuaca. Demikian hal dalam 
pengembangan aplikasi pemantauan konsumsi energi listrik juga telah memanfaatkan teknologi IoT. Sri Suryaningsih dkk mengembangkan perangkat pemantauan konsumsi energi menggunakan teknologi IoT. Hasil pengembangan menunjukkan system pemantauan telah bekerja dengan baik akan tetapi hasil pengukuran menunjukkan pengukuran arus dan tegangan masih kurang akurat[14].

Penelitian yang dilakukan Hartono dkk. mengembangkan sistem pemantauan konsumsi energi rumah tangga berbasis IoT dengan implementasi aplikasi server menggunakan software PHP. Berdasarkan hasil pengujian yang dilakukan Hartono dkk, menunjukkan akurasi pengukuran dengan membandingkan menggunakan alat ukur lain menunjukkan pembacaan arus untuk ketiga jenis beban tidak menunjukkan adanya perbedaan, sementara pengukuran tegangan memberikan perbedaan dengan rata-rata kesalahan mencapai $0,06 \%$ dan mampu menampilkan data pada ThingSpeak sebagai lokasi penyimpanan dan data visualisasi pengukuran hanya ditampilkan pada web ThingSpeak[15].

\subsection{Rancangbangun Sistem Online Monitoring Kualitas Air Waduk}

Rancangan sistem monitoring kualitas air waduk menggunakan tiga parameter ukur dengan menggunakan sensor pH Electrode (keasaman), sensor Turbidity (kekeruhan) dan sensor DS18B20 (suhu). Perangkat seri Arduino UNO sebagai mikrontroller yang digunakan untuk menerima dan mengolah data dari sensor. Selanjutnya, modul komunikasi online menggunakan WiFi modul ESP8266-01s. Luaran dari pembacaan sensor berupa data real-time yang dapat disimpan pada database online website ThingSpeak. Selain itu, aplikasi ThingView dapat membantu visualisasi data monitoring melalui perangkat Smartphone Diagram blok perancangan sistem seperti tampak pada Gambar 1.

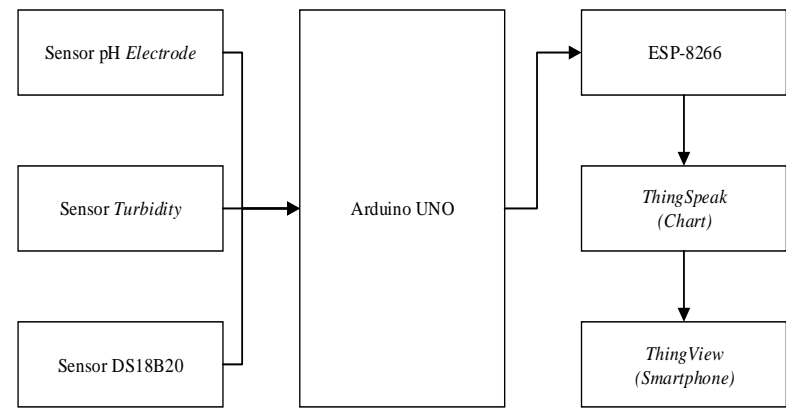

Gambar 1. Diagram Blok Rancangan Sistem

Gambar 1 menjelaskan sensor membaca kondisi level keasaman, kekeruhan dan suhu pada air waduk yang berupa nilai analog dan kemudian diubah digital melalui ADC (analog to digital converter) pada mikrokontroller Arduino. Kemudian data digital dikirim melalui modul wifi dengan akses internet ke database ThingSpeak setiap 1 menit/periode. pada ThingSpeak kemudian diakses menggunakan aplikasi ThingView melalui Smartphone

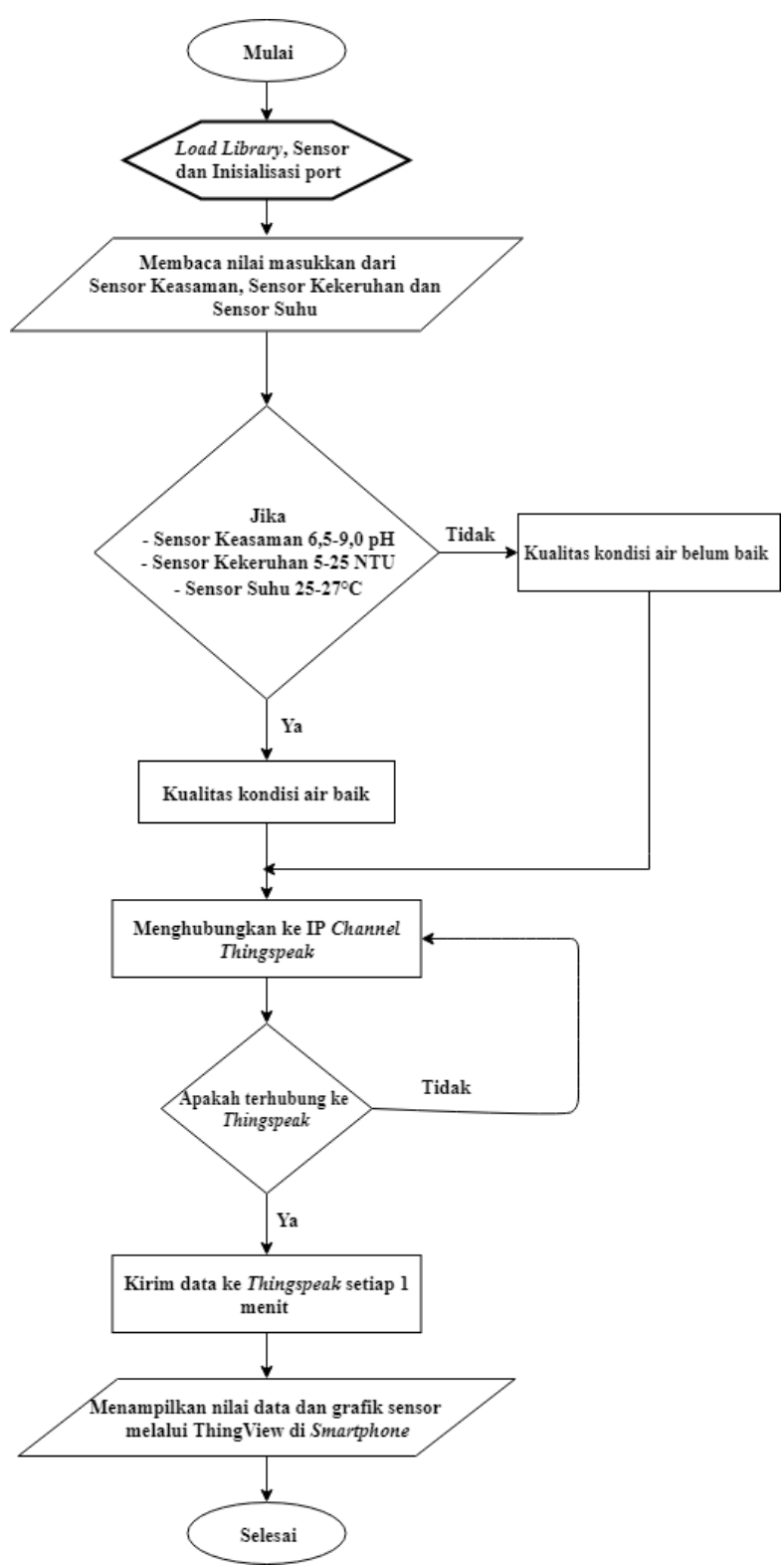

Gambar 2. Diagram Alir Perancangan Program

Gambar 2 merupakan diagram alir dari perancangan program untuk perangkat keras. Penerapan sistem awalnya dari Arduino akan memasukkan semua library yang dibutuhkan sesuai modul sensor yang digunakan pada pembuatan program ini, kemudian akan dilakukan untuk inisiasi port dari Arduino. Arduino akan membaca nilai masukan dari kondisi sensor keasaman, sensor kekeruhan, dan sensor suhu. Jika nilai masukan sensor sesuai dengan standar yang ditulis maka akan ada pilihan kondisi kualitas pada air waduk yaitu kualitas air waduk baik dan belum baik. Modul wifi ESP-01s akan menghubungkan ke IP channel ThingSpeak yang sudah 
dibuat sebelumnya. Jika IP channel belum terhubung, maka Arduino dan WiFi ESP-01s akan menghubungkan ulang kembali. Jika IP channel sudah terhubung, maka Arduino dengan WiFi ESP-01s yang sudah terkoneksi internet akan mengirimkan hasil pembacaan nilai ke tersebut. Nilai hasil pembacaan setiap sensor akan dikirimkan ke channel ThingSpeak setiap 1 menit. Nilai yang sudah dikirimkan ke channel ThingSpeak dapat diakses melalui web server ThingSpeak yang telah dibangun. Selain itu sebagai pendukung monitoring hasil pembacaan sensor dapat dilihat dengan menggunakan aplikasi ThingView yang terpasang pada Smartphone Android.

\section{Eksperimental dan Hasil}

3.1. Implementasi Protototipe dan Pengujian Sensor

Implementasi prototipe dapat dilihat pada Gambar 3. Setiap sensor teringerasi dengan perangkat mikrokontroller Arduino UNO dan wifi modul.

Proses pengujian pembacaan sensor dilakukan untuk mengambil data pada air di waduk di pemukiman warga. Sensor yang digunakan ialah $\mathrm{pH}$ Electrode untuk mengukur keasaman, Turbidity untuk mengukur kekeruhan dan DS18B20 untuk mengukur suhu. Peneliti melakukan sampel pengambilan data pada pagi, siang dan malam hari. Tujuannya adalah untuk membandingkan hasil pada setiap kodisi. Hasil pengujian dari pembacaan sensor pada waduk saat pagi hari dapat dilihat pada Tabel 1. Kemudian hasil pengujian pembacaan sensor pada siang hari dapat dilihat pada Tabel 2. Dan hasil pengujian sensor pada saat malam hari dapat dilihat pada Tabel 3 .

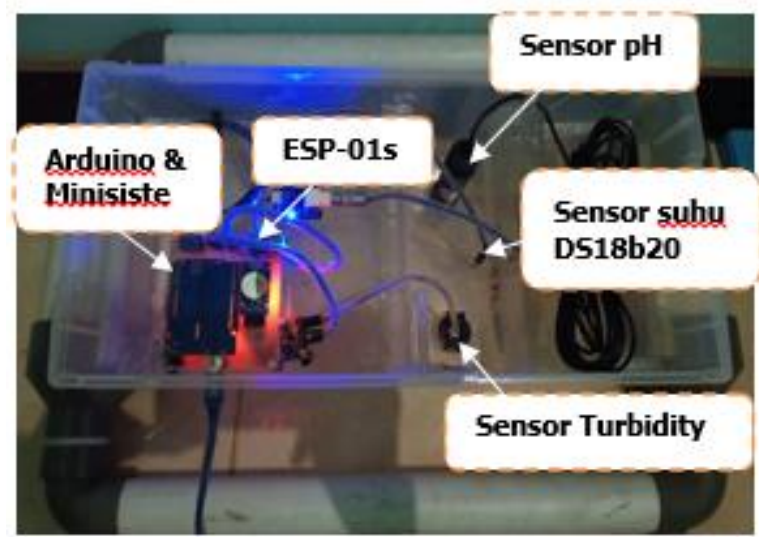

Gambar 3. Prototype Alat Monitoring

Tabel 1. Hasil Pengujian di Pagi Hari

\begin{tabular}{|c|c|c|c|c|c|c|c|c|c|}
\hline \multirow{2}{*}{ No } & \multicolumn{3}{|c|}{ Pengukuran Sensor } & \multicolumn{3}{|c|}{ Pengukuran Alat Ukur } & \multicolumn{3}{|c|}{ Kesalahan } \\
\hline & Keasaman & kekeruhan & suhu & pH Meter & Turbiditimeter & Thermometer & Keasaman & Kekeruhan & Suhu \\
\hline 1 & 7 & 8 & 22 & 6,4 & 20 & 26 & 0,6 & 12 & 4 \\
\hline 2 & 7 & 25 & 22 & 6,5 & 20 & 25 & 0,5 & 5 & 3 \\
\hline 3 & 7 & 34 & 22 & 6,6 & 21 & 25 & 0,4 & 13 & 3 \\
\hline 4 & 7 & 24 & 22 & 6,6 & 21 & 25 & 0,4 & 3 & 3 \\
\hline 5 & 7 & 23 & 22 & 6,6 & 20 & 25 & 0,4 & 3 & 3 \\
\hline 6 & 7 & 21 & 22 & 6,5 & 20 & 26 & 0,5 & 1 & 4 \\
\hline 7 & 7 & 30 & 22 & 6,6 & 21 & 25 & 0,4 & 9 & 3 \\
\hline 8 & 7 & 2 & 22 & 6,6 & 20 & 25 & 0,4 & 18 & 3 \\
\hline 9 & 7 & 8 & 22 & 6,6 & 21 & 25 & 0,4 & 13 & 3 \\
\hline 10 & 7 & 14 & 22 & 6,6 & 20 & 25 & 0,4 & 6 & 3 \\
\hline Rerata & $\mathrm{pH} 7$ & 18,9 NTU & $22^{\circ} \mathrm{C}$ & $\mathrm{pH} 6,56$ & 20,4 NTU & $25,2^{\circ} \mathrm{C}$ & 0,44 & 8,3 & 3,2 \\
\hline
\end{tabular}

Tabel 2. Hasil Pengujian di Siang Hari

\begin{tabular}{|c|c|c|c|c|c|c|c|c|c|}
\hline \multirow{2}{*}{ No } & \multicolumn{3}{|c|}{ Pengukuran Sensor } & \multicolumn{3}{|c|}{ Pengukuran Alat Ukur } & \multicolumn{3}{|c|}{ Kesalahan } \\
\hline & Keasaman & Kekeruhan & Suhu & pH Meter & Turbiditimeter & Thermometer & Keasaman & Kekeruhan & Suhu \\
\hline 1 & 7 & 16 & 23 & 6,7 & 16 & 30 & 0,3 & 0 & 7 \\
\hline 2 & 7 & 17 & 24 & 7 & 16 & 30 & 0 & 1 & 6 \\
\hline 3 & 7 & 16 & 24 & 6,9 & 16 & 30 & 0,1 & 0 & 6 \\
\hline 4 & 7 & 16 & 25 & 6,8 & 16 & 30 & 0,2 & 0 & 5 \\
\hline 5 & 7 & 31 & 24 & 6,7 & 17 & 30 & 0,3 & 14 & 6 \\
\hline 6 & 7 & 33 & 24 & 6,7 & 17 & 30 & 0,3 & 16 & 6 \\
\hline 7 & 7 & -3 & 24 & 6,6 & 16 & 30 & 0,4 & 19 & 6 \\
\hline 8 & 7 & 33 & 24 & 6,6 & 16 & 30 & 0,4 & 17 & 6 \\
\hline 9 & 7 & 5 & 24 & 6,6 & 16 & 30 & 0,4 & 11 & 6 \\
\hline 10 & 7 & 14 & 24 & 6,6 & 16 & 30 & 0,4 & 2 & 6 \\
\hline Rerata & $\mathrm{pH} 7$ & 17,8 NTU & $24^{\circ} \mathrm{C}$ & $\mathrm{pH} 6,72$ & 16,2 NTU & $30^{\circ} \mathrm{C}$ & 0,28 & 8 & 6 \\
\hline
\end{tabular}


Tabel 3. Hasil Pengujian di Malam Hari

\begin{tabular}{|c|c|c|c|c|c|c|c|c|c|}
\hline \multirow{2}{*}{ No } & \multicolumn{3}{|c|}{ Pengukuran Sensor } & \multicolumn{3}{|c|}{ Pengukuran Alat Ukur } & \multicolumn{3}{|c|}{ Kesalahan } \\
\hline & Keasaman & Kekeruhan & Suhu & pH Meter & Turbiditimeter & Thermometer & Keasaman & Kekeruhan & Suhu \\
\hline 1 & 7 & -2 & 24 & 6,6 & 17 & 26 & 0,4 & 19 & 2 \\
\hline 2 & 6 & 0 & 24 & 6,4 & 16 & 26 & 0,4 & 16 & 2 \\
\hline 3 & 6 & 32 & 24 & 6,4 & 16 & 27 & 0,4 & 16 & 3 \\
\hline 4 & 6 & 32 & 24 & 6,4 & 17 & 27 & 0,4 & 15 & 3 \\
\hline 5 & 6 & 17 & 24 & 6,3 & 17 & 27 & 0,3 & 0 & 3 \\
\hline 6 & 7 & 17 & 24 & 6,3 & 17 & 26 & 0,7 & 0 & 2 \\
\hline 7 & 7 & 44 & 24 & 6,4 & 16 & 27 & 0,6 & 28 & 3 \\
\hline 8 & 6 & -1 & 24 & 6,4 & 17 & 27 & 0,4 & 18 & 3 \\
\hline 9 & 6 & 25 & 24 & 6,4 & 17 & 26 & 0,4 & 8 & 2 \\
\hline 10 & 7 & 37 & 24 & 6,3 & 17 & 26 & 0,7 & 20 & 2 \\
\hline Rerata & $\mathrm{pH} 6,4$ & $20.1 \mathrm{NTU}$ & $24^{\circ} \mathrm{C}$ & $\mathrm{pH} 6,39$ & 16,7 NTU & $26,5^{\circ} \mathrm{C}$ & 0,47 & 14 & 2,5 \\
\hline
\end{tabular}

Tabel 1 menunjukkan hasil pengujian sensor keasaman, sensor kekeruhan dan sensor suhu pada pagi hari. Hasil dari pengujian diperoleh rata-rata tingkat keasaman pada pagi hari adalah $\mathrm{pH} 7$ dengan hasil pengukuran alat ukur pH 6,56 dan rata-rata kesalahan sebesar 0,44. Tingkat kekeruhan pada pagi hari ialah 18,9 NTU dengan hasil pengukuran alat ukur 20,4 NTU dan rata-rata kesalahan sebesar 8,3. Kemudian tingkat suhu pada pagi hari ialah $22^{\circ} \mathrm{C}$ dengan alat ukur $25,2^{\circ} \mathrm{C}$ serta rata-rata kesalahan sebesar 3,2. Tabel 2 menunjukkan hasil pengujian sensor siang hari dan diperoleh rata-rata tingkat keasaman $\mathrm{pH} 7$ dengan hasil pengukuran alat $\mathrm{pH}$ 6,72 dan diperoleh ratarata kesalahan sebesar 0,28. Tingkat kekeruhan pada siang hari ialah 17,8 NTU dengan hasil pengukuran alat ukur 16,2 NTU dan kesalahan sebesar 8. Kemudian tingkat suhu pada siang hari $24^{\circ} \mathrm{C}$ dengan pengukuran alat ukur $30^{\circ} \mathrm{C}$ diperoleh rata-rata kesalahan sebesar 6 .

Selanjutnya pada Tabel 3 menunjukkan hasil pengujian sensor malam hari, diperoleh rata-rata tingkat keasaman pada malam hari $\mathrm{pH} 6,4$ dengan hasil pengukuran alat ukur $\mathrm{pH}$ 6,39 dan diperoleh rata-rata kesalahan sebesar 0,47. Tingkat kekeruhan rata-rata 20,1 NTU dengan hasil pengukuran alat ukur 16,7 NTU dan diperoleh standar rata-rata kesalahan sebesar 14 . Kemudian tingkat suhu ialah $24^{\circ} \mathrm{C}$ dengan hasil rata-rata pengukuran alat ukur $26,5^{\circ} \mathrm{C}$ dan diperoleh kesalahan 2,5 .

\subsection{Penyimpanan Data Sensor melalui ThingSpeak}

Penyimpanan data sensor pada database ThingSpeak dilakukan secara real-time. Tampilan data berupa grafik chart dari setiap paramater ukur. Sistem menghubungan perangkat Arduino UNO dengan WiFi ESP8266-01s sehingga terkoneksi dengan aplikasi API ThingSpeak yang diperoleh melalui setup channel. Sebelum pemrosesan data dilakukan, sistem ini mengakses data SSID dan password yang terkoneksi dengan jaringan internet. Tampilan hasil pada web channel ThingSpeak dapat dilihat pada Gambar 4. Gambar 4 menunjukkan penampilan grafik masing-masing data pengukuran yakni level keasaman, kekeruhan dan suhu.

\subsection{Visualisasi menggunakan Aplikasi ThingView pada Smartphone}

Berdasarkan data yang didapatkan pada hasil grafik dari ThingSpeak juga dapat dilihat visualisasinya menggunakan aplikasi ThingView yang dipasang di Smartphone peneliti seperti yang ditunjukkan pada Gambar 5.

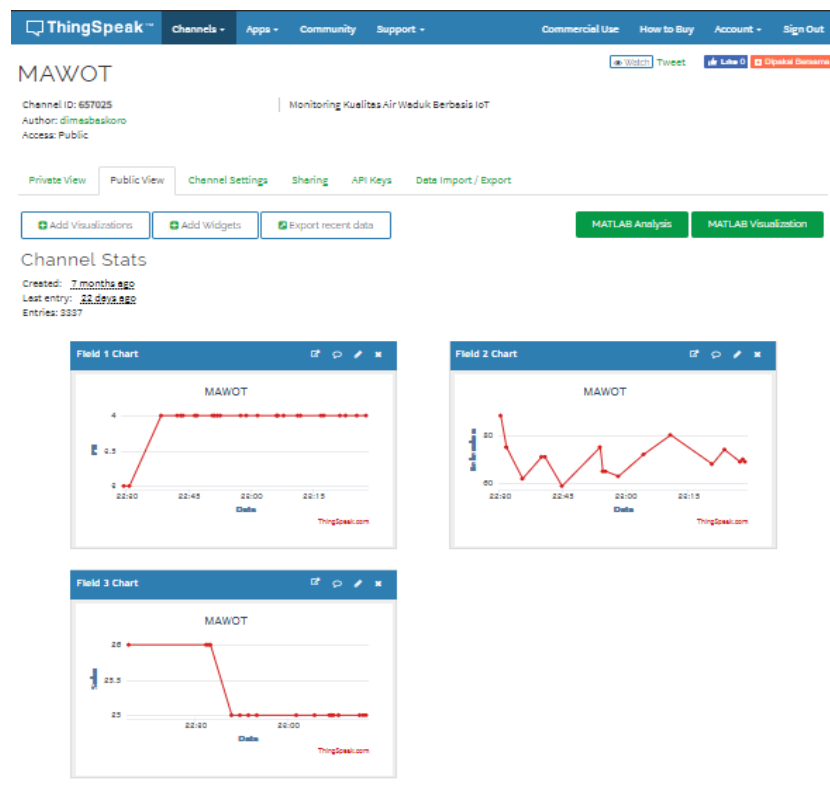

Gambar 4. Tampilan hasil pada web channel ThingSpeak

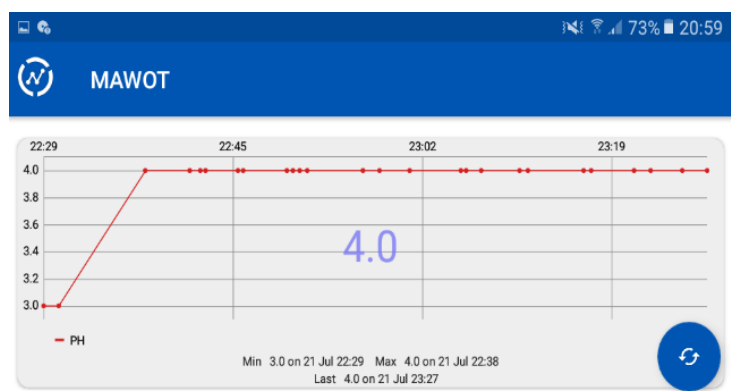

Gambar 5.a. Visualisasi Keasaman pada ThingView 

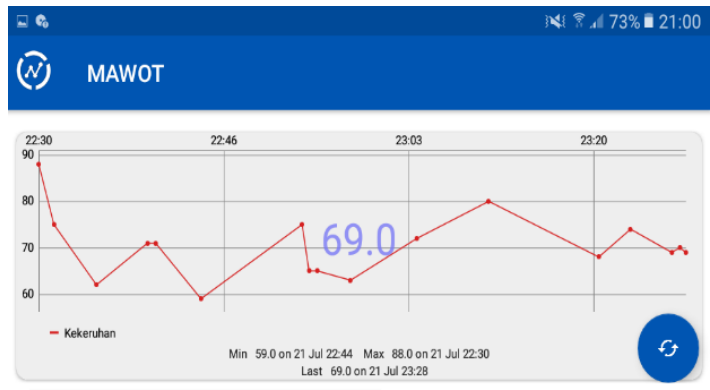

Gambar 5.b. Visualisasi Kekeruhan pada ThingView

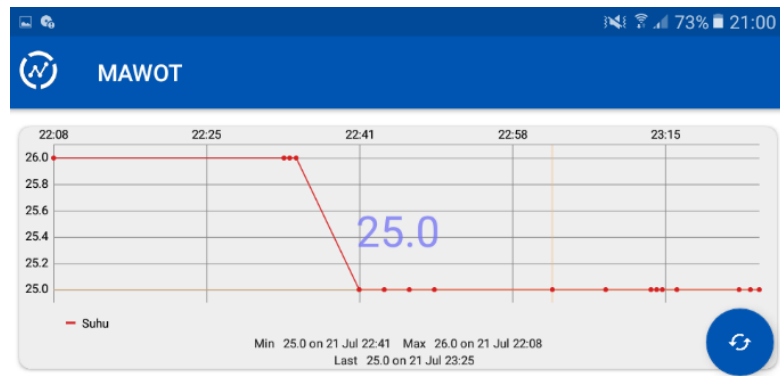

Gambar 5.c. Visualisasi Suhu pada ThingView

Pada Gambar 5 grafik dapat terpantau dari data waktu, tanggal, dan histori akses sistem. Hasil monitoring data kondisi air waduk pada ThingSpeak dapat divisualisasikan melalui Thing View.

\section{Kesimpulan}

Pentingnya menjaga kualitas air pada waduk yang berguna untuk penyediaan air masyarakat dan menjaga ekosistem dalam waduk. Maka, pada penelitian ini menerapkan media Internet Of Things untuk melakukan pemantauan kualitas air waduk dengan parameter kualitas air berdasarkan tingkat keasaman, kekeruhan, dan suhu. Hasil dari monitoring dapat ditampilkan pada website channel ThingSpeak dan aplikasi ThingView untuk dapat menampilkan hasil monitoring pada Smartphone. Diperoleh hasil pengujian sensor yaitu rata-rata tingkat keasaman pada pagi hari adalah $\mathrm{pH} 7$ hasil pengukuran alat ukur $\mathrm{pH}$ 6,56 dan rata-rata kesalahan sebesar 0,44, tingkat kekeruhan pada pagi hari ialah 18,9 NTU dengan hasil pengukuran alat ukur 20,4 NTU dan rata-rata kesalahan sebesar 8,3 kemudian tingkat suhu pada pagi hari ialah $22^{\circ} \mathrm{C}$ dengan alat ukur $25,2^{\circ} \mathrm{C}$ serta rata-rata kesalahan sebesar 3,2. Hasil pengujian sensor siang hari diperoleh rata-rata tingkat keasaman $\mathrm{pH} 7$ dengan hasil pengukuran alat $\mathrm{pH}$ 6,72 dan diperoleh rata-rata kesalahan sebesar 0,28. Tingkat kekeruhan pada siang hari ialah 17,8 NTU dengan hasil pengukuran alat ukur 16,2 NTU dan kesalahan sebesar 8. Kemudian tingkat suhu pada siang hari $24^{\circ} \mathrm{C}$ dengan pengukuran alat ukur $30^{\circ} \mathrm{C}$ diperoleh rata-rata kesalahan sebesar 6. Selanjutnya hasil pengujian sensor malam hari, diperoleh rata-rata tingkat keasaman pada malam hari $\mathrm{pH}$ 6,4 dengan hasil pengukuran alat ukur $\mathrm{pH}$ 6,39 dan diperoleh rata-rata kesalahan sebesar 0,47. Tingkat kekeruhan rata-rata 20,1 NTU dengan hasil pengukuran alat ukur 16,7 NTU dan diperoleh standar rata-rata kesalahan sebesar 14 . Kemudian tingkat suhu ialah $24^{\circ} \mathrm{C}$ dengan hasil rata-rata pengukuran alat ukur $26,5^{\circ} \mathrm{C}$ dan diperoleh kesalahan 2,5 . Pada pengiriman data menggunakan modul WiFi ESP01s sebagai media transfer data secara real-time yang terhubung dengan internet. Hasil monitoring dapat divisualisasikan melalui melalui aplikasi ThingView pada Smartphone. Pada sensor turbudity, data yang diperoleh masih fluktuatif disebabkan pembacaan sensor membutuhkan waktu lebih lama dalam pemrosesan data. Penelitian selanjutnya akan menambahkan sensor DO (Disolve Oxygen) untuk mendeteksi kadar oksigen dan terpasang solar panel sebagai sumber daya sistem.

\section{Referensi}

[1]. Raja F. (2016). Sistem perancangan monitoring pH air berbasis internet di PDAM TIRTA KEPRI. Universitas Maritim Raja Ali Haji, Provinsi Kepulauan Riau.

[2]. Astria, F., dkk. (2014). Rancang Bangun Alat Ukur pH dan Suhu Berbasis Short Message Service (SMS) Gateway. Jurnal MEKTRIK Vol. 1 No. 1. Pp 47-55.

[3]. Abdul Fatah,. (2016). Rancang Bangun Sistem Alat Ukur Turbidity untuk Analisis Kualitas Air Berbasis Arduino UNO. Pusat Penelitian Fisika Lembaga Ilmu Pengetahuan Indonesia (LIPI). Fibusi (JoF), Vol. 4 No. 1.

[4]. Monitoring water quality, Volunteer stream monitoring: A methods manual, http://southcenters.osu.edu/sites/southc/ files/sitelibrary/siteimages/WaterQualityConsiderations. pdf, accessed on April 11, 2018.

[5]. Anwar H., dkk. (2015). Rancang Bangun Sistem Telemetri Wireless Realtime Monitoring Kualitas Air Terintegrasi Dengan Automatic Sampling dan Aplikasi Database Berbasis Mikrokontroller, Universitas Pendidikan Indonesia, Pusat Penelitian Elektronika dan Telekomunikasi LIPI, Bandung.

[6]. Sukamto. (2016). Monitoring Perbandingan Kualitas Air Danau dan PDAM Menggunakan Sensor Turbidity, pH, dan Suhu berbasis Web, Politeknik Negeri Madiun. JEECAE Vol.1, No.1. Pp 37-45.

[7]. Pramusinto, Khanif dan Suryono. (2016). Sistem Monitoring Kekeruhan Air Menggunakan Jaringan Wireless Sensor system Berbasis Web. Youngster Physics Journal Vol. 5, No. 4. Pp 203-210.

[8]. Yudi Yulinus, dkk. (2015). . Online Monitoring Kualitas Air pada Budidaya Udang Berbasis WSN dan IoT. Pusat Penelitian Elektronika dan Telekomunikasi, Lembaga Ilmu Pengetahuan Indonesia. INKOM, Vol.10, No.2. Pp 81-86.

[9]. Heru Dwi, (2015). Pemantauan Kualitas Air Danau Semayang dan Danau Melintang di Kabupaten Kutai Kartanegara Menggunakan sistem Online Monitoring. JAI Vol. 8 No. 1. Pp 81-92.

[10]. Winarsis, dkk. (2016). Desain Sistem Monitoring Sistem Photovoltaic Berbasis Internet of Things (IoT). JNTETI, Vol. 5, No. 4. Pp 328-333 
[11]. Deni, dkk. (2016). Rancang Bangun Sistem Monitoring Kualitas Air. Seminar Nasional Teknologi Informasi. Pp 159-165.

[12]. Palimbuga, (2017). Sistem Monitoring Keasaman Berbasis Jaringan Nirkabel WiFi IP.

[13]. Rahajoeningoem, Tri dan Ivan Heru. (2017). Sistem Monitoring Cuaca dan Deteksi Banjir pada Android Berbasis Internet of Things (IoT). Universitas Komputer Indonesia. Pp 33-40.
[14]. Sri, dkk. Rancang Bangun Alat Pemantau Penggunaan Energi Listrik Rumah Tangga Berbasis Internet. Prosiding Seminar Nasional Fisika (E-Journal) SNF2016. Volume V Oktober.

[15]. Hartono, dkk. Pengembangan Sistem Pemantauan Konsumsi Energi Rumah Tangga Berbasis Internet of Things (IoT). Elkomnika Vol. 6 No. 3. Pp 357-366. 